\title{
The Forgotten Rational Thinking in the Hanbalite Thought With Special Reference to Ibn Taymiyya
}

\author{
AJHAR A. HAKIM
}

\begin{abstract}
The reputation of Hanbalite thinkers among academicians is one of an aggressive opponent to other Islamic fields of thought. They refute the scholars of Muslim theology, philosophy and mysticism on the basis of pure Islamic faith, represented they believe by the pious ancestors (al-salaf al-șalihh). According to the Hanbalites, true Islamic belief can only be derived from the Qur'an, the Sunnah of Prophet Muhammad and the first generation of companions. Ibn Taymiyya (d. 728 AH/1328 CE), the subject of this discussion belonged to the Hanbalite school of thought in Islam and was regarded as their most prominent representative. He has indeed come to be known as the father of the salafi1 ${ }^{-1}$ doctrine.
\end{abstract}

Key words: Ḥanbalite, Ibn Taymiyya, Islamic philosophy, Qur'an, sunna, generation (hudūth), divine will and knowledge, kalam, God's essence, reason, eternal creation, God's attributes, genera and species, Ash'arite and Mu'tazilite.

Ibn Taymiyya's adherence to Ibn Hanbal as a faithful, devoted follower has led many of his followers and opponents alike to believe that he was never in disagreement with his master. On the basis of this view, every contribution or thought that was Ibn Taymiyya's would be understood to be Hanbalite and even more dangerous is that, those who have not examined him carefully nor read him critically would think that every single notion of his was purely that of Ibn Hanbal. Even the detractors of Ibn Taymiyya who deeply respected Ibn Hanbal were only able to point out minuscule evidence against Ibn Taymiyya, claiming he had deviated from his master's teachings.

A thorough study of Ibn Taymiyya's writings shows him to be particularly critical toward the Hanbalite school and on some occasions to Ibn Hanbal himself. His independent evaluation was illustrated in his philosophical contributions to Islam in general and to Ibn Hanbal in particular. He had a deep involvement in philosophy, theology and mysticism, despite the fact that he appeared to have criticized these fields of thought.

1 Salafi is derived from salaf (the ancestors). The ancestors refers to those who were companions of the Prophet of Islam and they, according to the salafis, accepted what he told them without asking him questions about matters concerned. Despite whether or not this is true, the salafis believe that the good believer is the one who does the same as the Prophet's companions (șahäba) and does not object, discuss or ask questions about the Prophet's saying and the revelation.

Journal of Arabic and Islamic Studies • 14 (2014): 137-154 (C) Ahjar A. Hakim, Khalifa University of Science, Technology and Research, United Arab Emirates 
In retracing his philosophical thought, he appears profoundly influenced by philosophers like Abū 'l-Barakāt al-Baghdādī (d. 560 AH/1164 CE) and (Averroes) Ibn Rushd (d. 595 AH/1198 CE). He also respected and appreciated renowned mystics like Ibn 'Arabī (d. $638 \mathrm{AH} / 1240 \mathrm{CE})^{2}$ and 'Abd al-Qādir al-Jīlān̄̄ (d. 561 AH/1166 CE). ${ }^{3}$ His theology was extremely close to those schools which were traditionally and incorrectly regarded as astray and misguided, such as the likes of the Mu'tazilites, Karramiya and even some Shīite figures like Hishām ibn al-Hakam (d. 181 AH/798 CE) and Hishām al-Fūṭ̂̄ (flourished in the reign of the Abbasid Caliph Al-Ma'mūn) who were called by Ibn Taymiyya Hishāmiyya. ${ }^{4}$

If we agree that philosophy is a world view built on abstract concepts interpreting the structure of the universe, we find Ibn Taymiyya exhibits such an interpretation as shall be discussed here. He believed, unlike other Hanbalites, that the religion of Islam, specifically the Sunnī doctrine should be grounded on philosophy. Islam in Ibn Taymiyya's thought must be displayed or defended not only by the Qurān and Sunnah but with reasoning, as well. This was Ibn Taymiyya's main theses, that religion and reason accord each other. There is hardly a single religious issue that cannot be conceptualized rationally. ${ }^{5}$ By rationalizing religious issues, he attempted to explain Islam in philosophical terms covering aspects such as, the creation of the universe, God's attributes, the nature of things, the place of man and the interpretation of the Qur'an to name but a few.

Like al-Ghazālī, Ibn Taymiyya too aspired to construct a philosophical world view, leading one to believe that his philosophical thought was more coherent than that of alGhazālī. Al-Ghazālī remained perplexed between the Ash'arite doctrine, mysticism and Ibn Sinna's philosophy and then restored to eclecticism in order to combine elements from all

2 In his collection of treatises, Ibn Taymiyya states that Ibn 'Arabī (d. 638 AH/1240 CE) is the closest mystic to the religion of Islam and his books contain a lot of good words. Ibn 'Arabi according to Ibn Taymiyya approves the necessity of sharī' $a$ and asserts that good behavior and moral values in a way accord the religious authorities in Islam. People benefit from Ibn 'Arabī's works. See Majmū' al-rasā'il wa'l-masă'il (The Collection of Treatises and Questions), 4 vols., ed. Muhammad Rashīd Riḍā, Beirut: Dār al-Kutub al-Ilmiyya, 1983, vol. 1: 183.

3 In his Jāmi al-rasā'il (the Collection of Treatises) Ibn Taymiyya calls the mystic al-Jīlānī "one of the greatest shaykhs", and explains in a lengthy chapter al-Jīlānī's book Futūh al-ghayb (Revelations of the Unseen) where Ibn Taymiyya uses many of the mystics' vocabulary, such as inspiration (ilhäm), inward (bātin) and heart (qalb) as a source of knowledge. In his explanation of al-Jīlānī’s book Ibn Taymiyya stresses the importance of the believer's heart in knowing the judicial verdict in a matter we do not have a clear ruling on in Islamic jurisprudence. Inspiration in the believer's heart is an admitted way of deciding what is judicially prohibited and what is permitted. Ibn Taymiyya, Jämi`al-rasā' $i l$, ed. M. R. Sālim, Cairo: Mațba'at al-Madanī, 1969: 102.

4 Ibn Taymiyya deeply appreciated some of the Mu'tazilite's thinkers, such as Abū 'l-Husayn al-Bașrī (d. $436 \mathrm{AH} / 1044 \mathrm{CE}$ ), he praised him on many occasions for his belief in renewal in God's essence (tajaddud fì dhāt Allāh). Ibn Taymiyya implicitly appreciated Abu Hāshim al-Jubbā’’’’s (d. 321 AH/932 CE) theory of God's attributes as being states. The theory of states was interpreted by later theologians as universals. see Ibn Taymiyya's Muwäfaqat șah̄ihh al-manqūl li-șarīh al-ma'qūl (The Accordance of the Correct Religion with the Plain Reason), 2 vols., Beirut: Dār al-Kutub al-'Ilmiyya, 1985, vol. 2: 26 \& 400; Ibn Taymiyya's Jāmi 'al-rasā'il, 180, and for Abū 'l-Ḥusayn al-Bașrī's theory of renovation in God's essence, see al-Shahrastānī, Nihāyat al-iqdām fì ilm al-kalām, ed. A. Guillaume, London: Oxford University Press, 1934: 221.

5 Ibn Taymiyya, Dar' ta 'ärud al-'aql wa'l-naql (Prevention of the Contradiction Between Reason and Religion), ed. A. 'Abd al-Raḥmān, Beirut: Dār al-Kutub al-'Ilmiyya, 1997, vol. 9: 59. 
these fields. Ibn Taymiyya, meanwhile, chose a different direction in maintaining that reason and religion, Qur'an and Sunnah on one side and sound reason do not contradict each other. Ibn Taymiyya's writings never implied a blind commitment to any Muslim theologian. Even the works of al-Baghdādī and Ibn Rushd were not adopted by him in every single aspect. Rather, Ibn Taymiyya was a free thinker in building his own world view in a manner far from being eclectic. He adopted concepts from other leading thinkers but in the end created his own individual system.

\section{The Language of Ibn Taymiyya}

Ibn Taymiyya is probably one of the most misunderstood thinkers in Islam to date. There are many factors that played a role in this misunderstanding of his thought; he was one of them. The first factor is that his writings were of two levels; one was an apparent bitter hostile criticism and hidden beneath was the other deep, rational and open minded one. $\mathrm{He}$ was very harsh in his attack of speculative theology (kaläm) and philosophy, but at the same time adopted the bravest philosophical and theological themes. He accused some mystics of infidelity and atheism and yet was deeply influenced by them, particularly those who he accused. The second factor was that his disciples reformulated their master's thought in a way that made him appear a mere religious preacher and missionary. They employed the apparent level of his writings and propagated it as the core of the master's thinking. Those proponents of his who presented Ibn Taymiyya as merely a religious ideologist and Sunni fanatic, ignored the shaykh's philosophical thought as if it did not exist at all. ${ }^{6}$

For centuries Ibn Taymiyya's philosophical thought remained unknown, only some hints were found in the criticism of his opponents, without any systematic and comprehensive display or refutation to his thought. This criticism was brought on the basis of religious grounds, for one major purpose which was to accuse the shaykh al-islām of being an unbeliever. ${ }^{7}$ However, it can be said that these attacks which were voiced mainly by the Asharites, were not philosophical discussions but rather denouncements to the shaykh's position as a Hanbalite thinker. Both, his proponents and his opponents contributed to exclude Ibn Taymiyya's philosophy from public circulation and exhibition.

6 The Salafī school of Sunn̄i Islam in general and Wahhābī in particular which take Ibn Taymiyya as the second of their greatest shaykhs after Ibn Hanbal, did not admit Ibn Taymiyya's logical and philosophical thought. Muhammad ibn 'Abd al-Wahhāb (d. 1206 AH/1792 CE) for instance, never mentioned in his writings, although he admired Ibn Taymiyya, any of his shaykh's philosophical thoughts, such as God's attributes as ajnās wa-anwa', the generation in God's essence, the eternity of generation, etc.

7 See for instance Taqī al-Dīn al-Subkī (d. 756 AH/1356CE), al-Durra al-muḍ̂̀'a fì 'l-radd 'alā Ibn Taymiyya (The Shining Pearl in Refuting Ibn Taymiyya), Damascus: Mațba'at al-Taraqqī, 1247 AH, and Ibn Hajar al-Haytamī (d. 974 AH/1566 CE), al-Fatāwā al-hadīthiyya, 116. These two thinkers are repeatedly mentioned as critics of Ibn Taymiyya, though their criticism took a form of mentioning and numerating the issues that Ibn Taymiyya invented without precedence. And it should be noted that such criticism reflects not only an absence of a deep discussion but a misunderstanding of Ibn Taymiyya's thoughts too. 


\section{Reason and Revelation}

The question of reason and revelation has been discussed long before Ibn Taymiyya. In responding to this question, the early Islamic theologians focused on the notion of reference, namely, which one should be considered a reference for the other in terms of an attempt to understand the scripture. Should one take reason as a reference to comprehend the Qur'an or adapt reason according to the literal meaning of the Qur'ānic verses?

Although the question of reason and revelation has long been raised in the intellectual history of Islam, the style of discussion has changed in later times. Ibn Rushd (d. 595/1198) defended the notion of harmony between the two without approaching the question from the theologians' point of view. He focused on the notion of the truth rather than reference. According to him, truth is one, and it is impossible to imagine that the truth could contradict itself, whether expressed in religion or philosophy. In his book Faṣl al-Maqāl wa-Taqrīr mā bayn al-Hikma wa'l-Sharī'a min Ittișāl, he states "the truth does not oppose the truth, rather it accords it and proves it". ${ }^{8}$ This view represents the fundamental onset of Ibn Rushd's thought in which he would reconcile religion and philosophy. Ibn Rushd believed that the outward level (zāhir) of the religion (shar) accords the philosophy or the demonstrative discourse. Sometimes this accordance is apparent and does need an intellectual effort to develop it, on other occasions, where the $z \bar{a} h i r$ al-shar ${ }^{c}$ is different from the demonstration (burhān), we need to interpret the Qur'ān in order to bring the harmony back between it and the demonstrative discourse. As a result, Ibn Rushd maintained that the whole religion need not be interpreted. The interpretation $\left(t^{\prime} w \bar{l} l\right)$ should be exercised where a difference is noticed. ${ }^{9}$ The ordinary people, for Ibn Rushd, will not be mistaken if they believe in the literal aspect of religion ${ }^{10}$ because the outward corresponds the same philosophical truth but in representations (amthāl), ${ }^{11}$ while philosophy expresses the truth in a demonstrative method.

There are two important points about Ibn Rushd's theory of harmony between religion and philosophy. First, the true and correct philosophy for Ibn Rushd is that of Aristotle. Ibn Rushd immensely admired Aristotle and considered him a genius who had arrived at the truth. He regarded Aristotle as the embodiment of the development of the human intellect. His system is the best example of viewing the world in a demonstrative discourse. Second, both religion and philosophy are independent of each other and remain two different discourses although both disclose the same truth. Philosophy is the discourse of those who understand through demonstration while religion is the discourse of ordinary people whose way of understanding is rhetoric. The two discourses are different in their instruments and their influences on particular people. According to Ibn Rushd, people may be divided into

8 Ibn Rushd, Faṣl al-maqāl wa-taqrīr mā bayn al-hikma wa'l-sharī'a min ittișāl (The Decisive Treatise on the Harmony of Philosophy and Religion), Beirut: Dār al-Āfãq al-Jadīda, 1982: 19.

9 Ibid.: 7.

10 Ibid.: 37.

11 Ibn Rushd says: "That those things which cannot be known except in demonstration (burhān), because of their concealment, God was kind enough with His servants who are not able to understand by demonstration... and has given those amthāl (similes, examples or figures) and called them to believe them. All people can believe these amthāl by common evidence; I mean the dialectic and rhetoric". Ibid.: 27. 
three categories; each category has a particular ability of understanding a particular speech: the demonstrative speech, the argumentative speech, and the rhetorical speech. These speeches are different from each other in their way of thinking and intellectual tools employed by each. ${ }^{12}$ In applying this theory of discourses in Islamic society, Ibn Rushd would say that the people of the demonstrative speech are the philosophers and particularly the peripatetic ones. Mutakallimūn (Muslim theologians) are the people of argument or dialectic (jadal) who can be named, according to Ibn Rushd, people of dialectic interpretation (ahl al-ta'wìl al-jadalī). Finally, there are the ordinary people, the people of rhetorical speech, who understand things through figures and representation. ${ }^{13}$

Ibn Taymiyya endeavored to maintain the notion of harmony between reason and scripture but in a way different from Ibn Rushd. The points that already mentioned and characterized Ibn Rushd's theory of harmony between revelation and philosophy were given a different approach by shaykh al-isläm. Reason according to Ibn Taymiyya is equivalent to plain, sound rational thinking produced by the nature (fitra) of the human being. It is not a predetermined system of thought brought and intended to be harmonized with the scripture. According to him, God has provided man with an innate nature or fitra. This fitra can be defined by two main components: first, by the structure of the human mind and second, by psychological dispositions and tendencies. Regarding the human mind, Ibn Taymiyya believed that man's way of thinking is based on two factors. The first factor being that one thinks universally, and universals (kulliyyāt) are the tools one uses to comprehend the world. Universals are just mental perceptions and do not exist in the real world. Truth exists objectively as individual sensible things. The second factor is that which characterizes the structure of the human mind in that the mind has been provided with inborn thoughts that are correct in themselves without a need to prove them, such as arithmetic, where one is half of two. ${ }^{14}$ The second natural component of the human being is one's innate tendency to search for that which is beneficial $(n \bar{a} f i)$ for him. The human being has a natural motivation that enables him to discriminate between that which causes pain or causes pleasure (ladhdha). Pleasure here meaning that which benefits one's very own existence. Ibn Taymiyya supported this theory with some Qur'ānic verses: "Magnify the Name of thy Lord the Most High who created and shaped, who determined and guided" (87:3), and "Our Lord is He who gave everything its creation, then guided it" (20:50). Guidance (hidāya) in the Qurāan, according to Ibn Taymiyya does not have a religious connotation; rather it means exactly this natural inclination toward good, "human beings are born with a natural disposition to love what is good for their body from food and drinks". ${ }^{15}$

Searching for that which benefits man is not confined to material good alone. According to Ibn Taymiyya, it is much more than this as it includes seeking the truth or that which leads to the real unity of God. Possessing the truth or seeking it, is part of one's

12 Ibn Rushd, Faṣl al-maqāl, 31

13 Ibid.: 33, and Ibn Rushd, al-Kashf 'an manāhij al-'adilla fi 'aqā’id al-milla (Clarifying the Systems of Proof in the Beliefs of the Nation), Beirut: Dār al-Āfāq al-Jadīda, 1982: 46.

14 Ibn Taymiyya, Majmū'al-fatāwā (The Collection of Legal Opinions), collected by 'Abd al-Rahmān Q. Najdī, 37 vols., Riyadh: 1398 AH, vol. 9: 71.

15 Ibn Taymiyya, Dar' ta 'ārud al-'aql wa 'l-naql, vol. 5: 289. 
fitra because knowing the God implies the ultimate benefit to human existence. "Fitra is a readiness (isti' $d \bar{a} d$ ) for knowledge." "The availability of a certain fitra in human beings does not necessarily imply that every individual would reach the truth; it is the will of the human being which makes the natural disposition able or not able to comprehend the haqq (God). This will is the main power that makes the potential tendency real and actualized. The fitra, as Ibn Taymiyya explained is a kind of $i s t i d \bar{a} d$ in the human being, and it is the responsibility of an individual to develop this disposition towards reaching the ultimate truth, namely, God. He states: "the conclusion is that the human being has been provided with the fitra of power (ability) for knowing and willing this knowledge". ${ }^{17}$

The question remains, what role or position does that revelation play or occupy in this understanding. Ibn Taymiyya expounded, in very clear statements that human beings possess the capacity to reach the real meaning of the unity of God or any other issue that religion has brought independently and without the assistance of revelation. He said: "The soul of the human being possesses a natural ability toward thinking and inference which makes him in no need for external teachings, since every child is born with this fitra; this necessarily implies that the potentiality of having knowledge is inherent in every human. And this is the required conclusion." 18

In one of his lengthy discussions, Ibn Taymiyya interprets the Prophetic tradition: "every child is born upon fițra then his parents make him a Jew, a Christian, or a Magian" (Sahīh Bukhārī, 2658). Fițra here means hanīfiyya (uprightness) which is no more than following a particular path for gaining the best interests, benefits and knowing the truth (haqq) which essentially serves the existence of man. ${ }^{19}$ Fitra does not mean the religion of Islam or that the child born is a Muslim as Ibn Hanbal understood, nor a pure or empty nature similar to a white sheet. ${ }^{20}$ Haniffiyya refers to certain powers represented by dispositions inclined toward material and non-material benefits. Man, therefore, is capable of independently knowing everything that revelation delivered to him, and he is capable of reasoning to know God without the help of revelation, "the fitra of man contains a power that entails one to believe in haqq and willing the benefit, and then establishing the existence of the Creator". ${ }^{21}$ Ibn Taymiyya emphasized that the human being's fitra does not need Aristotle or any other philosopher to tell us about the truth. It is obvious to notice here, however, the differences between Ibn Taymiyya and Ibn Rushd. Ibn Taymiyya agreed that people are different from each other in comprehending the truth, and not everyone is able to arrive at it on his own, some people need revelation to know the truth. At times, even ordinary people remain fundamentally in need of their fitra in order to accept the revelation. This acceptance does not imply the full knowledge of the haqq, but the believer still has to develop the truth brought by revelation by pondering upon it. In this respect, Ibn Taymiyya used terms such as provocation or solicitation and education. The Revelation provokes, reminds and educates people of the haqq. ${ }^{22}$ The fitra, therefore, which stands

16 Ibn Taymiyya, Dar' ta 'ārud, vol. 5: 290.

17 Ibid.: 290.

18 Ibid.: 320 .

19 Ibid.: 327.

20 Ibid.: $349-360 \& 319$.

21 Ibid.: 326-327.

22 Ibid.: 320.

$J A I S ・ 14$ (2014): 137-154 
behind the willingness to contemplate about God independently, stands behind the acceptance of the Prophets' messages by ordinary people, as well. Without the human fitra, neither the independent thinker would approach the truth nor do the ordinary men accept the message of the Prophet. ${ }^{23}$ The theory that may look shocking here is the emphasis of Ibn Taymiyya on a point that, if people are all able to reach the $h a q q$ and their benefit and they all have the will to avoid corruption and bad thoughts coming from their environment, there would be no need for the revelation. ${ }^{24}$ The other important difference with Ibn Rushd is that reason and revelation cannot forever be separated from each other. Contrary to Ibn Taymiyya, Ibn Rushd viewed both scripture and philosophy as representing two kinds of discourses, each group of people inclined by nature to a certain discourse differ in their way of attaining the knowledge of the perfect God. ${ }^{25}$ Ibn Taymiyya admitted the independent method that people follow according to their capacity, but differed in holding that, once the independent thinker reaches this truth he will love God as the most perfect Being, and this love of God would lead him necessarily to worship Him, "it has been established that the human soul contains the power of loving God and being in servitude of Him and believing in His religion faithfully". ${ }^{26}$

Ibn Taymiyya here used the word luzüm meaning concomitance since independent thinking implies yalzamu, worshipping God as accepting the religion of Islam. ${ }^{27}$ As a matter of fact, if people are of two kinds in knowing and reaching the perfect God as a source of the whole existence, they will meet and unite in adopting religion in the end. Ibn Taymiyya seems closer here to Ibn Țufayl (d. 581 AH/1185 CE) than Ibn Rushd. In Hayy Ibn Yaqzāan (Alive, Son of Awake), Ibn Țufayl's famous fable, we read that after achieving the truth of God in an independent way Hayy worshipped God agreeing with the religious man Asāl who came from another island and told him the same truth but in a religious context. Ibn Țufayl says: "Then he (Ḥayy Ibn Yaqzān) began to ask him (Asāl) concerning the precepts which the Messengers of God had delivered and the rites of worship which he had obtained. Asāl then told him of Prayer, Alms, Fasting and Pilgrimage and other such external observances. Ḥayy Ibn Yaqzān accepted these and took it upon himself and practiced, in obedience to his command, of whose veracity he was very well assured". ${ }^{28}$

23 Ibn Taymiyya, Dar' ta' ārud, vol. 5: 328-329.

24 Ibid.: 320

25 In his Faṣl al-maqāl, 27, Ibn Rushd mentions three discourses: demonstrative, dialectical and rhetorical and declares that people by nature are not all able to accept the demonstrative sayings, p. 31, since the inward (bätin) of the Qur'ann would not be disclosed except to the people of demonstration. The second group of people cannot understand things demonstratively, and because of this God has given them similes (amthāl), or representational figures to make them understand.

26 Ibn Taymiyya, Dar' ta 'árud, vol. 5: 321-322.

27 Ibid.: 331

28 Abū Bakr Ibn Țufayl, The History of Hayy Ibn Yaqzān, trans. Simon Ockley, New York: Frederick A. Stokes Company Publishers, 1708: 167-168, and Sami S. Hawi, Islamic Naturalism and Mysticism: A Philosophical Study of Ibn Ṭfayl's Hayy Ibn Yaqzān, Leiden: Brill, 1974: 25. 


\section{Ibn Taymiyya and God's attributes}

Ibn Taymiyya emphasized in all his writings that the true philosophy is that which depends solely on the attributes of God, as the only true philosophical level relates God to the world. In this view Ibn Taymiyya, obviously was thinking on the same lines of Islamic kalām. However, he uncompromisingly maintained the concept of the unity of God refusing the intermediary world of intellects of the Muslim emanationist philosophers that are filling the space between God and the physical world. Moreover, shaykh al-isläm would judge the philosophers' system of thought on the basis of this intermediary level. This shall provide us with a good understanding of his thought and his stance toward other Muslim philosophers. Here, it is clear why Ibn Rushd was admired by Ibn Taymiyya.

Unlike al-Ghazāli and the early Muslim theologians, Ibn Taymiyya held that God's attributes should not be dealt with on the basis of the Arabic language philology. The early theologians' formulation of God's attributes was evolved on the duality of the name ('ism) and meaning (mana $)$. The Mu'tazilites believed that the true unity of God should be affirmed on the principle that God obtains only names because names not only preserve the unity of God pure and void of any kind of multiplicity, but names affirm the reality of God. The function of names is to indicate the essence of God and His being as such, not the opposite. $^{29}$

The Ash'arites, on the other hand, believed that God not only has names but attributes of ma'āni (senses or meanings) as well. Names do not indicate the essence of the one who is named, but indicate the ma'ān $\bar{\imath}$ subsisting in an essence. For the Ash'arites the name $a l$ álim (all knowing) points to the knowledge that resides in the essence of God but does not directly indicate the essence. These meanings (ma $\bar{a} n \bar{\imath})$ according to the Arabic language are infinitives from where the names are derived. The attributes of Knowledge, Might, Will, Life, Hearing, Seeing and Speech are neither God Himself nor other than Him at the same time. ${ }^{30}$

Abū Hāshim al-Jubbā̄̄ (d. 321 AH/933 CE), the Mu'tazilite thinker, searched for a compromise between his own school and the Ash'arites. He tried to find a middle ground between the two. He referred to God's attributes as states $(a h w \bar{a} l)$. Abū Hāshim maintained that hâal "state" is a proposition like 'Zayd is knowing' (Zaydun 'älimun) to assert and referentially to indicate Zayd being knowing. ${ }^{31}$

The theory of states $(a h w \bar{a} l)$ was interpreted and later understood by Ash'arite thinkers as a theory of universals (kulliyyāt). 'Abd al-Karīm al-Shahrastānī (d. 548 AH/1153 CE) in his book Nihāyat al-Iqdām fì Ilm al-Kalām ${ }^{32}$ and Sayf al-Dīn al-Āmidī (d. 631 AH/1333 CE), another Ash'arite theologian, in his Ghāyat al-Marām fì Ilm al-Kalām, believed that states mean universals. ${ }^{33}$ Those theologians who developed the early theory of states and

29 Abū 'l-Hasan al-Ash'arī, Maqālāt al-islāmiyȳ̄n wa-ikhtilāf al-muṣallīn, ed. H. Ritter, Istanbul/Wiesbaden 1929-33: 524; 'Abd al-Karīm al-Shahrastān̄̄, al-Milal wa l-nihhal, 2 vols., ed. M. Kaylān̄̄, Beirut: Dār al-Márifa, 1989: 39; and FRANK 1978: 15.

30 al-Shahrastānī, al-Milal wa'l-niḥal, 76.

31 FRANK, "Ḥâl", 345.

32 al-Shahrastānī, Nihāyat al-Iqdām, 13-18 \& 144.

33 Sayf al-Dīn al-Āmidī, Ghāyat al-marām fì 'ilm al-kalām (Goal of the Aspiration in the Science of Kalam), ed. M. 'Abd al-Lațif, Cairo: al-Majlis al-A'lā, 1971: 31-33. 
made it more philosophical by adding a new condition stating that if the theory of states could be correct it should be said that universals exist only in mind and do not have any objective reality. In doing so, Abū Hāshim's statement "states are neither existent nor nonexistent" 34 would be understood to mean that states do not exist in the objective world but do exist in one's mind.

This effort of refining and developing the theory of states attempted to justify the early Ash'arite's position that adopted the theory of states like Abū Bakr al-Bāqillānī (d. 403 AH/1013 CE) and Abū 'l-Ma'ālī al-Juwayn̄̄ (d. 478 AH/1085 CE). Al-Juwaynī admitted that states are mental causes through which we can derive the names of God. Rather than reiterating the traditional view held by his school of thought, that God's attributes are ma'ānī subsisting in God's essence from which God's names are derived; we should say that God's attributes are mental ma'ānī or causes from which names of God are derived or caused. ${ }^{35}$ This was a radical change in the Ash'arite school introduced by virtue of the Mu'tazilite Abū Hāshim's theory of states.

Ibn Taymiyya goes one step further in depicting the nature of God's attributes and states that God's attributes are species and genera (ajnās wa-anwāa). In other words, they are the most general universals. Ibn Taymiyya did not take the position of attributes as being universals just for determining the nature of attributes in its relation with God as early theologians endeavored to do; he intended rather to establish a different interpretation of the theory of God's creation of the world. In as much as God's attributes are species and genera, they should have by necessity, particulars and those particulars are the existents that God created. However, bear in mind that the theory of God's attributes as universals is not meant to explain how God knows things, but how God creates things, it is stated for an ontological purpose, not an epistemological one.

By viewing God's attributes as universals Ibn Taymiyya prepared his own theory of creation. The major accomplishment he made is that he eliminated all sorts of intermediate entities between God and the cosmos, such as intellects, souls and even terrestrial spheres. Notice here that Ibn Taymiyya removed all sorts of Neo-Platonist elements that prevailed in the history of Islamic philosophy. Moreover, the structure of Ibn Taymiyya's view is very economical in a sense that the metaphysics are now void of all complicated worlds that may stand beyond this real world.

The emanationist philosophers like Al-Fārābī and Ibn Sīnā filled the universe with insensible entities in order to explain the relationship between God and the cosmos. Their major philosophical principle was, "from One only one can emanate", and multiplicity would appear emanated from the first intellect, who is one and can issue many at the same time. The basic principle of emanationist philosophers "from One only one can emanate" was rightly criticized by al-Ghazālī and later by other Muslim thinkers like Fakhr al-Dīn alRāzī (d. 606 AH/ 1209 CE) and Ibn Taymiyya. Al-Ghazālī maintained that this principle is self-contradictory if God is one in all His aspects; the first intellect should be one in all its aspects too and multiplicity cannot come out of it as well. Alternatively, if we assume that

34 al-Shahrastānī, al-Milal wa 'l-niḥal, 63.

35 Abū 'l-Ma'ālī al-Juwaynī, al-Shāmil fì ușūl al-dīn, ed. A. S. Nashshār, F. B. 'Awn and S. Mukhtār, Alexandria: Munsha’at al-Ma'ārif, 1969: 269. 
the first intellect is the source of multiplicity, then we should admit that His source (God) is not perfectly one. ${ }^{36}$

\section{God's Self-generation as an alternative for philosophers and Mutakallimun}

For Ibn Taymiyya, it is only God and the physical cosmos that exist; there is no intermediate world between the two. Ibn Taymiyya invented a new philosophical term for giving a rational interpretation of the birth of the universe, he called it God's selfgeneration. The first stage is when God's attributes would be determined in particular forms. The fundamental attributes that are responsible for producing things are Knowledge and Will. All other attributes participate in the process of creation, but these two attributes remain the main tools of creation. All other attributes are predicates of creatures after being particularized. The generation in God's essence is nothing but the birth of particular forms in God's essence; each form pertaining to one individual creature. The existents of the cosmos have their origins first as forms in God, and then these forms are embodied as sensible creatures in the next stage of creation. The term used frequently in Ibn Taymiyya's philosophy to name the form that was already born in God's essence is a tașauur mu'ayan (determined concept). ${ }^{37}$

Ibn Taymiyya believed that all God's attributes are eternal and universals and concomitant to God's essence. The attributes of Life, Hearing, Sight, Love and Passion are in a process of particularization, and they become predicates of a certain creature. The cosmos and human being are characterized by the same attributes that belong to God, but in a particular way. The universe, therefore, is no more than the attributes of God after being actualized in singular forms. ${ }^{38}$

Although Ibn Taymiyya believed in eternal creation, he refused to accept that a definite thing or a certain sensible object is eternal, only the process of determining things is eternal. This process is based on the principle of causality that the effect comes immediately after the availability of the cause. Cause and effect do not exist together at the same time, one, rather, comes after another. This succession or sequence does not imply any time separation between the attributes and their particular determined entities. The frequently repeated example given by Ibn Taymiyya to describe the role of this succession has been the act of striking and pain, where the pain comes immediately after one is struck. In this example Ibn Taymiyya stated that cause and effect are not synchronized, they do not exist in the same moment, but the effect of necessity comes after the cause without delay.

God's determined Will and Knowledge are forms ${ }^{39}$ that are generated in God's essence, but they are neither archetype nor Platonic Forms, they are rather individual forms and every form is a form of a specified and definite creature. Abū 'l-Barākāt al-Baghdādī was

36 Abū Ḥāmid al-Ghazālī, Tahāfut al-falāsifah (Incoherence of the Philosophers), ed. Maurice Bouyges, Beirut: Dār al-Mashriq, 1986: 101

37 Ibn Taymiyya, Dar' ta 'ärud, vol. 10: 169-170; Majmü' al-fatāwā, vol. 6: 326.

38 Ibn Taymiyya, Muwāfaqat șah̄ịh al-manqūl li-șarìh al-ma 'qül (The Accordance of the True Tradition and the Plain Reason), 2 vols., Beirut: Dār al-Kutub al-Tlmiyya, 1985, vol. 2: 110.

39 In Majmü $\bar{u}^{`}$ al-rasa $\bar{a}$ 'il, vol. 4: 31, Ibn Taymiyya described that determined will and knowledge can be named as form and possible (mumkin), that being produced in God's essence. 
the first philosopher, according to Ibn Taymiyya, who adopted this generation in God's essence. Indeed al-Baghdādī in his search for an alternative to Ibn Sīnā's active intellect (al-'aql al-fa'cal), proposed the possibility of God's attributes generating forms in $\operatorname{God}^{40}$ alBaghdādī was not clear enough in deciding the generation of forms in God, but he hinted at such an assumption. Besides that, al-Baghdādī did not formulate the theory of creation as divided into stages like that of Ibn Taymiyya. Nonetheless, al-Baghdādī was still revered as a great philosopher for Ibn Taymiyya because of his replacement of heavenly intellects with God's attributes as the means of creation. This is why Ibn Taymiyya admired him so much that he regarded him as the closest philosopher to the religion of Islam. The other eminent philosopher he looked up to was Ibn Rushd for his theory of eternal creation. ${ }^{41}$

The first stage of creation is named by Ibn Taymiyya as the stage of generation (hudüth) and the second stage is named the stage of creation (khalq). In the second stage the forms are embodied in sensible and concrete existents. In the same manner, the relation between form and sensible existent is a causal one. The sensible existent comes immediately after the form existed, and the form exists immediately after the attribute of God exists.

Ibn Taymiyya refuted the theologians' theory of creation. God for him should be prior to anything else and active eternally at the same time. It is unacceptable to assume, as Muslim theologians do, that God exists and does not create when God by nature is active $(f \bar{a} i l){ }^{42}$ Ibn Taymiyya calls the theologians' attitude an attitude of suspension $(\mathrm{ta} t \bar{c} \bar{l} l)^{43}$ since God stays in pre-eternity without doing anything in their view. The priority of God for shaykh al-isläm, can be stated by causal succession in time that God's attributes precede the production of the forms in God's essence. ${ }^{44}$

Having maintained the concept of subsequence or succession (ta $\bar{a} q u b)$, everything in the universe should be described as both cause and effect together. The forms that generated in God's essence are effects of God's attributes, they are causes of sensible existents, and sensible existents by turn are causes of something else. One of Ibn Taymiyya's favorite concepts was the creation of things one after another (shay'an ba'd shay). ${ }^{45}$

Creation is eternal, and nothingness ('adam) is an illusion. God himself does not create out of nothing but creates things out of preceding things (shay'an min shay'). ${ }^{46}$ The Qur'ān and the Prophetic tradition, according to shaykh al-islām, assure that everything in the universe was created out of matter and time (min mäddatin wa-mudda). ${ }^{47}$

40 Abū 'l-Barākāt al-Baghdādī, al-Mu'tabar fì 'l-hikma al-ilāhiyya, 3 vols., Haydar Abad 1385 AH, vol. 3: $164 \& 176$.

41 Ibn Taymiyya, Majmū' al-fatāwā, vol. 6: 158.

42 Ibn Taymiyya, Muwāfaqat șahịh, vol. 1: 275.

43 Ibid.: 89.

44 Ibn Taymiyya, Minhāj al-sunna al-nabawiyya, 4 vols., Beirut: al-Maktaba al-'Tlmiyya, [no date], vol. 1: $57-58$ \& 122-123.

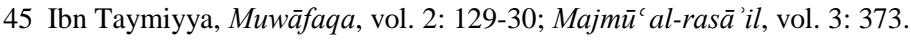

46 Ibn Taymiyya, Kitāab al-nubuwwāt (The Book of Prophethoods), Beirut: al-Maktaba al-'Așriyya, 2003: 370.

47 Ibn Taymiyya, Majmū'al-rasā’ il, vol. 4: 368. 
Ibn Taymiyya believed himself faithful to the Qur'ān and the Prophetic tradition (Sunna) and considered his thought as an interpretation of the religious texts. $\mathrm{He}$ maintained that the Qurānic God should be defined by fundamental principles: His priority over everything else except His attributes, God being perfect and eternally active and the impossibility to imagine that God was inactive even for one moment, however short that span of time may be.

\section{The perfection of God and the concept of generation}

The philosophers' concept of the perfection of God represents in one way or the other an obstacle for developing their own theories of creation. God, for them, is a perfect Being, $\mathrm{He}$, therefore does not need to use any of His attributes, particularly His Will. For them, the being that uses his will does so to have something that he already does not have. The will, by definition is to desire something needed. In as much as God is a perfect Being, His will according to the Muslim philosophers, should not be understood this way, because the perfect Being does not need anything. ${ }^{48}$

This understanding of God as a perfect Being prevented philosophers from describing God as a real agent, Ibn Sīnā for example, endeavored to interpret God's attributes making them as working as the emanation process itself. God's will, His generosity and His knowledge are all the same as the emanation. ${ }^{49}$ For Ibn Sīnā, any different understanding of God's attributes would mar the perfection of God and depict Him as in need for something outside of His own Magnificence. Ibn Rushd agreed on this principle as the acknowledgement of the Will of God would mean that God needs something outside of Himself. $^{50}$

Abū 'l-Barakāt al-Baghdādī was the first to criticize Ibn Sīnā's concept of the perfection of God. According to him, philosophers cannot regard God as active through His will, because God is perfect. While according to Ibn Sīnā, God does not need to satisfy any deficiency in His essence or respond to any demand in Himself. ${ }^{51}$

For al-Baghdādī, the philosophers' assumption of the perfection of God was wrong. The opposite is required; that is to say the starting point in viewing God philosophically is asserting that God is already perfect and then any activity that can be supposed will not negatively affect the perfection of Him. His attributes do not show the lack of God, but the perfect God uses His attributes because of His perfection. ${ }^{52}$

By turning the concept of God's perfection, God philosophically will be able to work through His attributes. God is willing and all knowing. Having established the perfection of God as an axiom and starting point, God would be a real active agent. ${ }^{53}$ The starting

48 Ibn Taymiyya, Dar' ta 'ārud, vol. 5: 265 \& 294-295.

49 Avicenna, The Metaphysics of the Healing, A parallel English-Arabic text translated, introduced and annotated by Michael Marmura, Utah: Brigham Young University Press, 2005: 295-296.

50 Ibn Rushd, Tahāfut al-Tahāfut (The Incoherence of the Incoherence), Beirut: Dār al-Fikr al-Lubnānī, 1993: 240.

51 al-Baghdādī, al-Mu 'tabar, vol. 3: 75.

52 Ibid: 76.

53 Ibid.: 162.

$J A I S ・ 14$ (2014): 137-154 
premise in this sort of thinking is that God is a perfect Being, and this would allow one to post God's attributes as philosophical means by which God creates and issues the multiplicity directly from Himself.

\section{Time and motion}

Time and motion in Ibn Taymiyya's thought are eternally concomitant to the generation of forms and things. Their eternity is not the eternity of independent substances; rather time and motion accompany essentially the eternity of the generation of all kinds. The generation in God's essence is a sort of motion, but this motion is not exactly the motion of Aristotelian philosophy. It is not a movement from place to place or from generation to corruption or from corruption to generation. Ibn Taymiyya did not give a full definition of motion as a generation. This motion must be addressed as long as there is a generation in God's essence. Ibn Taymiyya who continually attempted to base his philosophical theories on the tradition of the Prophet (sunna) found support from religious texts and some Sunnī traditionalists. To him, God is attributed as alive; this implies that every alive being is a moving one. Life and motionlessness are contradictory concepts. Ibn Taymiyya said: "the leaders (imāms) of the Sunn̄i people like Harb al-Kirmānī (d. 279 AH/893 CE) and 'Uthmān bin Sa'̄id al-Dārimī (d. 280 AH/ 894 CE) and others clearly spell the word motion and they considered this belief as the belief of the Sunni people of the past and present time". 'Uthmān bin $\mathrm{Sa}^{\top} \overline{\mathrm{l}} \mathrm{d}$ and others said: "motion is concomitant with life that is to say, everything alive is in motion, and they considered denial of this to be a Jahmiyya trait". 54 Ibn Taymiyya concluded that God is alive, and motion is eternal with His life.

Time too is eternal as God is eternally producing the forms from His own attributes. This implies of necessity that time was not created in a definite moment. Ibn Taymiyya never made a separation between the eternal consecution of things and time. He did not classify time into many categories such as dahr and surmud, Ibn Taymiyya believed in one kind of time, which is the time of the birth of things and events. He believed, as well, that time is eternal in a way parallel to the process of creation itself, namely that, time counts with the form being generated a while after the existence of God's attributes as genera and species. The generation of forms gives rise to the eternity of motion and time as well. Bear in mind that according to Ibn Taymiyya, eternity meant the succession of things starting from the essence of God and continuing its generation outside of God's Self forever.

\section{The principle of causality is comprehensive}

The principle of causality is comprehensive, and everything in the universe is ruled by the duality of cause and effect, except God Himself, who is prior to everything else. Ibn Taymiyya did not use the term "First Cause" to name God although God is essentially the initiator of everything. shaykh al-isläm was aware of the consequences of using such a term. He did not refrain from using it because it was a philosophers' term or because he

54 Ibn Taymiyya, Muwāfaqa, vol. 1: 308-309. 
wanted to be faithful to the traditional names agreed upon by the conservatives, rather he did not use it because he intentionally wanted to avoid all the implications of this name. The term "First Cause" in the Al-Fārābī and Ibn Sīnā means that the first effect of the First Cause is eternal too, in as much as the First Cause exists the effect exists as well. The priority of God would be confined to a logical one not a priority in time reflected in the succession of things. Al-Fārābī was clear in this coexistence of the cause (God) and effect (the First Intellect), "Once the First exists, and that existence is His own so the rest of existents would exist by necessity". 55 This notion was rejected by Ibn Taymiyya as we have already seen. Ibn Taymiyya insisted upon the infinite chain of creatures coming one after another. He described the theory of the first cause as arbitrary since God according to him is a cause, but should not be depicted as the first cause. ${ }^{56}$

The principle of causality is a very essential ground in Ibn Taymiyya's thought. This point makes him different from early Muslim theologians and mystics as well. He understood the principle of causality in the way mentioned above that the cause must precede its effect. It is exceedingly difficult to determine the time between the cause and effect, but the cause must come before the effect. In this view, Ibn Taymiyya maintained the priority of God as $\mathrm{He}$ is the first Being. Individual forms are born from the determination of God's attributes in God's essence.

This principle is not restricted to a series of stages of creation, but the relationship between things in the universe is a causal one. Ibn Taymiyya harshly criticized the early theologians who denied the causality. He considered them the defamers of the religion of Islam. According to him, God has placed in things their own natures, where everything produces another thing from its own kind. Wheat produces wheat, humans produce humans and God's will works according to the nature of things. For him, the denial of the principle of causality is tantamount to the denial of the wisdom of God Himself. On many occasions he stressed the statement: "God has created things that contain each other" ${ }^{, 57}$ in a way that "there is a power in fire that necessitates heat, a power in water that necessitates cold and a power in the eye necessitates vision". 58

Ibn Taymiyya denied the early Muslim theologians claim that God has a free will in a sense that $\mathrm{He}$ does whatever He wills to do and leaves whatever He wills to leave. Both Mu'tazilites and Ash'arites believed that God could produce barley from wheat or a monkey from a human being. ${ }^{59}$ They did not believe in the necessary causal relation between things. For them, God is free in doing a thing or its opposite as God is not under any obligation whatsoever. If man's observation of things shows that two things may come after one another regularly such as satisfaction after eating, the growth of plants after irrigation, the burning of cotton after setting it aflame, then this means that some early theologians held that God has created the effect at the time of the cause, but the effect

55 Abū Nașr al-Fārābī, The Political Regime (al-Siyasa al-Madaniyya), Arabic text, edited by Fauzi M. Nijjar, Beyrouth: Imprimerie Catholique, 1964: 48.

56 Ibn Taymiyya, Muwäfaqa, vol. 2: 199.

57 Ibn Taymiyya, Majmü $\bar{u}^{\prime}$ al-rasā' $i l$, vol. 1: 100.

58 Ibid., vol. 3: 112.

59 Abū Rashīd al-Nīsābūrī, al-Masāỉl fí 'l-ikhtiläf bayn al-bașriyyīn wa 'l-baghdādiyyīn (The Questions on Which the Basrans and the Baghdadis Are Opposed), ed. M. Ziyada \& R. al-Sayyid, Beirut: Ma'had alInmā' al-'Arabī, 1979: 133-139.

$J A I S ・ 14$ (2014): 137-154 
would not be produced because of the cause. The concomitant of the cause and effect is just a habitual succession but definitely not a natural process or causal impact. This understanding was regarded by Ibn Taymiyya as un-Islamic, irrational and one that makes a mockery of religion. ${ }^{60}$

Ibn Taymiyya not only established a coherent vision of the world on the basis of the principle of causality but maintained that God's acts are consistent with this law. Every action taken by God has its own motive, nothing done by Him is meaningless or for a futile purpose. God has provided His creation with its own nature and the choice of good or evil actions. Good and evil deeds are a consequence of the innate nature inherent in creation. Every action in the world according to Ibn Taymiyya's theory is a sort of manifestation of God's action, similar to the theory of the distribution of God's universal will into an infinite number of wills. Nature is synonymous to the Will of God; all things in the world operate according to the law of causality.

Ibn Taymiyya criticized many of the Sunni people for their perspective of God's actions as inexplicable. Contrary to this, he maintained that God's actions are caused by the motive of human interest (maslaha) and defined the goodness and ugliness of actions as a result of convenience and feasibility (muläama). What is good for the human being is that which is convenient for him and the opposite holds equally true. ${ }^{61}$

Ibn Taymiyya's thinking here appears to be close to that of the Mu'tazilites, who adopted the concept of human interest and God's creation of good for mankind, but he criticized them for their middle position they had taken. He regarded them as those who attempted to find an explanation for God's actions in order to avoid the futility in God's authority. For Ibn Taymiyya, the Mu'tazilites fell into futility when they ignored giving any explanation of God's own motive. God, according to them is a mere agent who acts in the interests of others and does not of Himself have any interest in His actions. Shaykh al-isläm stated that the doer himself acts in His own interest as well. In as much as God acts for the sake of the human beings' benefit His objective of guiding them to give praise and thanks to Him is met in return. ${ }^{62}$

Ibn Taymiyya completely refused the stance of orthodox Muslims who believed in the absolute power and free will of God. For him, those believers were not thinking appropriately as they had made God's actions in the final analysis purposeless, and made human beings appear powerless in understanding their position and destiny in the world. In his discussion, Ibn Taymiyya repeatedly stated that God's actions should be understood on the basis of God's wisdom and causation (hikma wa-ta $9 \bar{l} l) .{ }^{63}$

Some Muslim sects like the Ash'arites, the Hanbalites and other mystics believed that any assumption of the existence of motives or causes behind God's actions implies that God is an imperfect Being. If God acts, motivated by a cause, He will perfect Himself with this action. The only way to assert the perfection of God is by maintaining that He acts according to His comprehensive power and free will or pure will (mahd al-mashì $a$ ), and the only thing that a good believer should do is to ask God for His mercy in his earthly life

60 Ibn Taymiyya, Majmū'al-rasā’il, vol. 1: 100; Majmū'al-fatāwā, vol. 3: 100 \& vol. 9: 287.

61 Ibn Taymiyya, Majmū ‘ al-rasä'il, vol. 5: 286.

62 Ibn Taymiyya, al-Qadä' wa'l-qadar, 258-259.

63 Ibn Taymiyya, Majmū'al-rasä’il, vol. 5: 286. 
and the hereafter. ${ }^{64}$ Ibn Taymiyya unhesitatingly disagreed with such an understanding. He believed that God is a perfect Being before acting, and His actions are His expression of perfection and not the contrary.

In addition to this, still in keeping with his line of thought, Ibn Taymiyya presented another brave argument in the history of Islam. The universe does not contain secrets or inaccessible areas. God, for him, has not created an unknown world nor has He left any dark or unreachable mysteries which human beings are unable to comprehend. Once again, this contradicted the traditional or conservative understanding that Islamic thought had witnessed. For Ibn Taymiyya, everything in the universe is within man's capacity to comprehend. If there is anything that we do not understand, this is on account of human limitations not because God has intended to keep it secret. It is insolent, according to him, to accept the notion that God has created an inexplicable and mysterious world. The wisdom of God completely contradicts such an assumption. He often posed the question. ${ }^{65}$

Here, Ibn Taymiyya contributed in giving his answer to one of the thorny questions raised by the Mu'tazilite thinker Abū Ishāq al-Naẓz̄ām (d. 231 AH/845 CE) who maintained that God is unable to torture a child because His intrinsic nature as purely good does not make Him capable of doing so. Ibn Taymiyya who proceeded from the concept of human interest (mașlaha) denied God's torture of a child, because He does not have any interest in doing so. ${ }^{66}$ Ibn Taymiyya's answer is significantly different from the earlier Sunnī line of thinking which strongly upheld the concept of God's ability to do anything He wishes. Ibn Taymiyya was one of a few thinkers who strove to rationalize Islamic theology into a system of thoughts that would make religious issues comprehensible and explicable.

\section{Conclusion}

Ibn Taymiyya was one of the leading thinkers who assessed Islamic theology by using the basic concepts of philosophy. He did not wholeheartedly adopt any Greek system of thought but selected only concepts, like ajnās $w a-a n w \bar{a}$, form, causality and nature among others and developed them in his own context. On one hand, he seemed very keen on philosophy, and could be considered a philosopher while, on the other hand, he reformed Islamic theology by taking the rational interpretation of Islam as his approach. His opponents rejected some of his daring theses, and his disciples considered him one of the greatest authorities in Islam, but his creative thoughts remain till this day elusive to many.

In Islamic history, Ibn Taymiyya holds an exceptionally high position as an intellect in regard to his theories. Further elaboration on the destiny of philosophy in the Sunni texts after the death of Ibn Rushd is deemed necessary. His contribution opened the window to elevate the importance of the conceptual and philosophical thinking in Islam and endeavored to remove the possible contradiction between reason and religion.

64 Ibn Taymiyya, Risāla fì tahqūq al-tawakkul, in Jāmi` al-rasā'il, 98.

65 Ibn Taymiyya, Tafsīr sūrat al-Ikhlāṣ, reviewed by Țāhā Y. Shāhīn, Cairo: Dār al-Ṭibā'a al-Muhammadiyya, [no date]: 259.

66 Ibn Taymiyya, Majmū̌ ${ }^{\prime}$ l-rasā’ $i l$, vol. 5: 286-294.

$J A I S \cdot 14$ (2014): 137-154 


\section{Bibliography}

\section{Primary Sources}

al-ĀMIDĪ, Sayf al-Dīn. Ghāyat al-marām fì ilm al-kalām. Ed. H. 'Abd al-Lațīf. Cairo: al-Majlis al-'Alā, 1971.

al-ASH'ARĪ, Abū 'l-Ḥasan. Maqālāt al-islāmiyyīn wa-ikhtilāf al-muṣallīn. Ed. H. Ritter. Istanbul: Wiesbaden, 1929-33.

al-BAGHDĀDĪ, Hibat Allāh Abū 'l-Barakāt. Kitāb al-mu'tabar fì 'l-hikma al-ilāhiyya. 3 vols. Hyderabad, $1939 / 1357$.

al-FĀRĀBĪ, Abū Nașr. The Political Regime (al-Siyasa al-madaniyya). Edited by Fauzi M. Nijjar. Beyrouth: Imprimerie Catholique, 1964.

al-GHAZĀLİ, Abū Hāàmid. Tahāfut al-falāsifa. Ed. M. Bouyges, Intro. M. Fakhry. Beirut: Dār al- Mashriq, 1983.

IBN RUSHD. Tahäfut al-tahäfut (The Incoherence of the Incoherence). Trans. Simon Van Den Bergh. 2 vols. London: Luzac, 1954.

-. K. Fașl al-maqāl wa-taqrīr mā bayna al-hikma wa'l-sharī'a min ittișāl (The Decisive Treatise on the Harmony of Philosophy and Religion). Beirut: Dār al-Āfāq al-Jadīda, 1982.

[IBN SīnĀ] Avicenna. The Metaphysics of the Healing. A parallel English-Arabic text / translated, introduced and annotated by Michael MARMURA. Utah: Brigham Young University Press, 2005.

IBN TAYMIYYA. Dar' ta'āruḍ al-'aql wa'l-naql, ed. A. 'Abd al-Raḥmān. 5 vols. Beirut: Dār al-Kutub al'Ilmiyya, 1997.

_. Jāmi`al-rasā̉il. Ed. M. R. Sālim. Cairo: Mațba‘at al-Madanī, 1969.

—. Majmū' fatāwā shaykh al-islām Ibn Taymiyya. 36 vols. Riyād: Maktabat al-Ḥukūma, 1968/1386.

—. Majmū' 'at al-rasā’il wa 'l-masā̉il. Ed. M. R. Riḍā. 5 vols. Beirut: Dār al-Kutub al-'Tlmiyya, 1983.

—. Muwāfaqaț șaḥịh al-manqūl li-șarīh al-ma'qūl. 2 vols. Beirut: Dār al-Kutub al-'Tlmiyya, 1985.

—. Minhāj al-sunna al-nabawiyya. 4 vols. Beirut: al-Maktaba al-Ilmiyya, n.d.

—. Tafsìr sūrat al-Ikhlāṣ. Reviewed by Țāhā Y. Shāhīn. Cairo: Dār al-Ṭibā'a al-Muhammadiyya, no date.

IBN ȚUFAYL, Abū Bakr. The History of Hayy Ibn Yaqzān / trans. Simon OCKLEY. New York: Frederick A. Stokes Company Publishers, 1708.

al-Juwhyñ̄, Abū 'l-Ma'̄ālī. al-Shāmil fì ușūl al-dīn. Ed. A. S. Nashshār, F.B. 'Awn and S. Mukhtār. Alexandria: Munsha'at al-Ma'ārif, 1969.

al-QUR'ĀN. The Koran Interpreted. Trans. A. J. Arberry. London: Oxford University Press, 1964.

al-SHAHRAStĀNĪ, 'Abd al-Karīm. al-Milal wa 'l-niḥal. 2 vols. Ed. M. Kaylānī. Beirut: Dār al-Ma'rifa. 1989.

—. Nihāyat al-iqdām fì 'ilm al-kalām. Ed. A. Guillaume. London: Oxford University Press, 1934.

\section{Secondary Sources}

FRANK, Richard M. 1978. Beings and Their Attributes. State University of New York Press, Albany.

- . "Hāll". Encyclopaedia of Islam, $2^{\text {nd }}$ ed., Supplement 3: 343-48.

HAwI, Sami S. 1974. Islamic Naturalism and Mysticism: A Philosophical Study of Ibn Tufayl's Hayy Ibn Yaqzānn. E.J. Brill, Leiden.

\section{Additional Readings}

AARON, Richard I. 1967. The Theory of Universals. $2^{\text {nd }}$ ed. Clarendon Press, Oxford.

ABRAHAMOV, Binyamin. 1988. "Al-Ghazālī’s Theory of Causality". Studia Islamica, 67-68: 89-111.

- 1992. "Ibn Taymiyya on the Agreement of Reason with Tradition". The Muslim World, 82/3-4: 256-72.

Allard, Michel. 1965. Le Problème des attributs divins dans la doctrine d'al-Ash'arī. Imprimerie Catholique, Beirut.

ARNALDEZ, R. "Ibn Rushd”. Encyclopaedia of Islam, 2 ${ }^{\text {nd }}$ ed., vol. iii: 909-20. 
BENCHEIKH, J. E. “Abū 'l-Husayn al-Bașrî”. Encyclopaedia of Islam, $2^{\text {nd }}$ ed., Suppl., 1-6: 25-6. BurRell, David B. 1990. "Creation or Emanation”. In: BuRRELL/ MCGINN (eds.) 1990: 27-37.

— / MCGINN, Bernard (eds.). 1990. God and Creation. Notre Dame Press, University of Notre Dame.

DAVIDSON, Herbert. 1978. Proofs for Eternity, Creation and Existence of God in Medieval Islamic and Jewish Philosophy. Oxford University Press, London.

FALES, Evan. 1990. Causation and Universals. Routledge, London \& New York.

al-FĀRĀBĪ, Abū Nașr. K. Ārā ahl al-Madīna al-fădila. $5^{\text {th }}$ Ed. Beirut: Dār al-Mashriq, 1986.

- Al-Fārābì on the Perfect state. Revised, trans. into English, with an introduction, Richard Walzer. Oxford: Clarendon Press, 1985.

FRANK, Richard M. 1988. “Attribute, Attribution, and Being: Three Islamic Views”. In: MoREwEDGE (ed.) 1988: 258-78

al-HAMADHĀNĪ, 'Abd al-Jabbār. al-Mughn̄̄ fì abwāb al-tawhịd wa'l-'adl. vol. 6:2. Ed. G. Anawati, I. Madkūr; vol. 11. Ed. M. 'Alī al-Najjār, 'A. H. al-Najjār. Cairo: al-Dār al-Mișriyya, n.d.

—. Sharh al-usūl al-khamsa . Ed. A. K. 'Uthmān. Cairo: Maktabat Wahba, 1965.

IBN ḦAZM. al-Fișal fì 'l-milal wa 'l-ahwä' wa'l-nihhal. 5 vols. Baghdad: Maktabat al-Muthannā, n.d.

KoGAN, Barry S. 1981. "Averroes and the Theory of Emanation". Medieval Studies, 43: 384-404.

—. 1984. "Eternity and Origination: Averroes Discourse on the Manner of the World Existence". In: MARMURA (ed.) 1984: 203-235.

LAOUST, Henri. 1939. Essai sur les doctrines sociales et politiques de Taki-d-dīn Ahmad Ibn Taimiya. Imprimerie de l'Institut Français d'Archéologie Orientale, Le Caire.

—. "Hanābila". Encyclopaedia of Islam, $2^{\text {nd }}$ ed., vol. iii: 158-62.

—. "Ibn Taymiyya". Encyclopaedia of Islam, $2^{\text {nd }}$ ed., vol. iii: 951-55.

LeAman, Oliver. 1988. Averroes and his Philosophy. Clarendon Press, Oxford.

- 1979. "Avicenna's Chapter on Universals in the Isagoge of his Shifä"”. In: WelCH / CACHIA (eds.) 1979: 34-56.

MARmURA, M. E. (ed.). 1984. Islamic Theology and Philosophy. Studies in Honor of G. Hourani. SUNY Press, Albany.

MicheL, Thomas. 1983. "Ibn Tamiyya's Critique of Falsafa". Hamdard Islamicus, 6: 3-14.

Morewedge, P. (ed.). 1988. The Philosophies of Existence, Ancient and Medieval. Fordham University Press, New York.

Welch, Alford T. / CACHIA, Pierre (eds.). 1979. Islam: Past Influence and Present Challenge. Edinburgh University Press, Edinburgh.

AJHAR A. HAKIM, Khalifa University of Science, Technology and Research, Sharjah, U.A.E. \hakim.ajhar@kustar.ac.ae 